\title{
Michel Corajoud and Parc Départemental du Sausset
}

\section{Fabio Di Carlo}

To cite this article: Fabio Di Carlo (2015) Michel Corajoud and Parc Départemental du Sausset, Journal of Landscape Architecture, 10:3, 68-77, DOI: 10.1080/18626033.2015.1094917

To link to this article: http://dx.doi.org/10.1080/18626033.2015.1094917

$$
\text { 曲 Published online: } 23 \text { Sep } 2015 .
$$

\begin{tabular}{|c|c|}
\hline$\sqrt{6}$ & Submit your article to this journal \\
\hline \multicolumn{2}{|c|}{ 山ll Article views: 2} \\
\hline Q & View related articles \lceil \\
\hline Q & View Crossmark data $\leftrightharpoons \nearrow$ \\
\hline
\end{tabular}




\section{Michel Corajoud and Parc Départemental du Sausset}

\section{Abstract}

Among the many significant contributions France has made to contemporary landscape architecture, Michel Corajoud counts as one of the towering figures and his Parc Départemental du Sausset as one of the great park visions of the 1980s. In France, and beyond, Corajoud has emerged as one of the protagonists of the great era that this decade has come to be considered in landscape architecture. He was the primary promoter of teaching landscape in France, the creator of the first landscape architecture school (ENSP at Versailles), a visionary and able designer of large projects. If Parc de la Villette can be considered the most significant project of this period, in terms of innovation of public open spaces, Parc Départemental $\mathrm{du}$ Sausset is, for its large and complex vision, an exemplary model of a periurban park that combines rural fringe, suburban settlements, and urban infrastructure with an ecological sensitivity that had not previously been envisioned in other parks. Sausset is a project that works on all scales of the landscape, from the garden to the natural park, and to agricultural fields. It makes multiple references to French landscape history. It presents itself as an ever-changing place, where landscape processes, with their evolutionary dynamics, can be perceived and witnessed by its users. Above all, Sausset is a park that successfully defines the philosophical dialectics between modernity and post-modernity by expressing a tension between innovation and the revival of a strong tradition.

French landscape heritage / Michel Corajoud / rural patterns / suburban parks / urban forestry
The re-invention of the suburban park

Parc Départemental du Sausset, framed in the cultural scene of late modernism in the 1970 s and early 1980 s, can be considered an important legacy of the twentieth century; a turning point in park design and an experience that combines a unique landscape figure with many new post-World War II Western cultural attitudes. Several advances were realized in the park that were subsequently developed into much-discussed themes and projects, such as the social and ecological roles of urban parks and landscape projects within the planning processes for urban development and the recomposition of territories.

The new key elements informing the design of Sausset are closely connected and operate at different conceptual levels. The first concerns landscape planning and an interest in the rural fringe areas that result from the process of urban growth, the recovery of large urban park design, and of urban forestry, as well as urban ecology studies. The second is linked to the design process and includes both linguistic and formal experiment, the articulation of the parts of a park, and the introduction of a new emphasis on the evolutionary dynamics of its asset, defining social functions and its relation with its context.

Different from projects in the early 1980s, like Parc de la Villette and the public spaces of Barcelona that were both designed by architects, Sausset is unique and the first among the seminal projects of the decade designed by a landscape architect. With this park, one can see the rise of the new profession of landscape architecture, which, until then, at least in France, had had no relevance in the debate on the transformation of modern cities.

After the post-war reconstruction era, Parc du Sausset represented a first search for a new response to public open spaces; one clearly oriented towards the landscape. [1] The project epitomized the search for a type of park that enhanced the natural environment within the construction of new suburbs, both in Paris and in many other big cities. It is, perhaps, also 
Figure 1 Site of Parc Départemental du Sausset before realization. Picketing works on the original tabula rasa. Elizabeth Lennard (1981), painting on photo on front cover of L'Architecture d'Aujourd'hui 218, 1981.

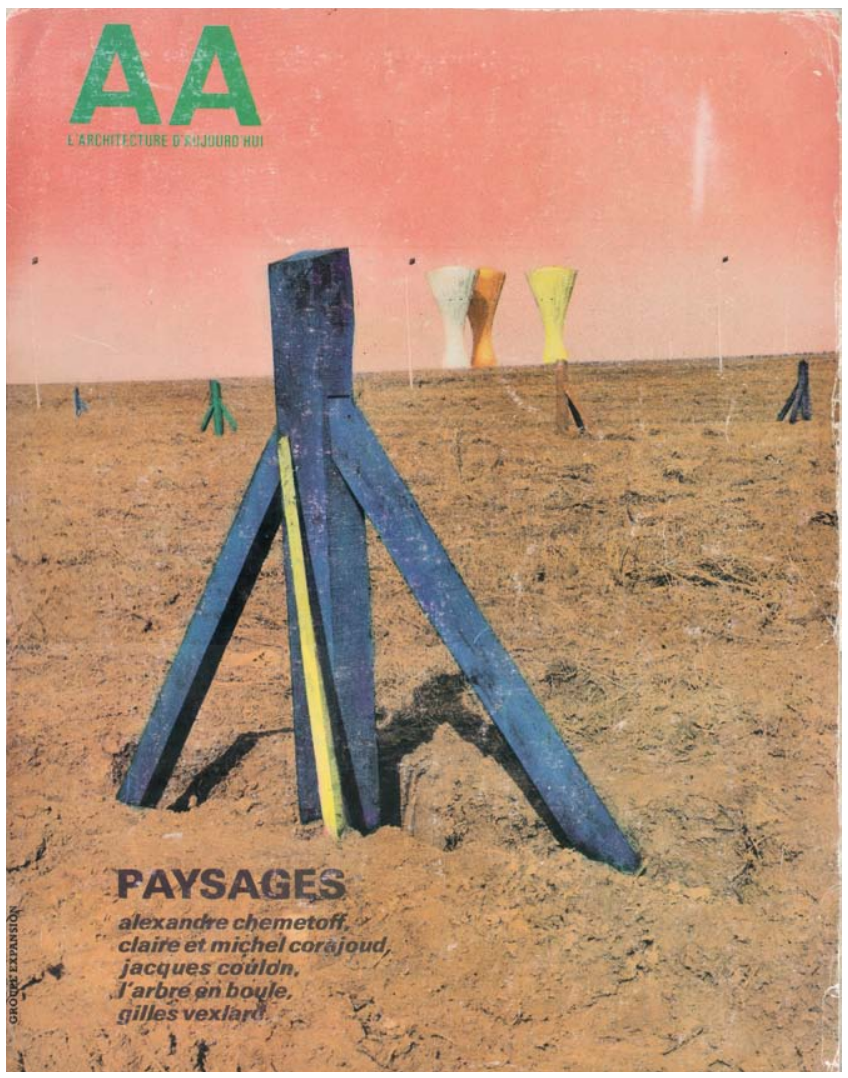

the first result of Corajoud's long militancy, begun in the 1970s with the projects of Parc de Villeneuve (today Parc Jean Verlhac) in Grenoble and Parc des Coudrays at Elancourt-Maurepas, which claimed for landscape architects the same prerogatives enjoyed by architects (Blanchon-Caillot 2007).

In addition, Parc Départemental du Sausset was one of the great parks and landscape visions of the 1980s that was concerned strictly with an identification of a new landscape for new suburban settlements. It marks a 'before' and 'after', which influenced subsequent projects and will leave a deep mark on the future decades of landscape culture.

The recent passing of Michel Corajoud provides an opportunity to draw a profile of this designer that supplements an understanding of the park itself and describes the evolution of landscape architecture thought in France during the 1980s, and his influence on it.

\section{Michel Corajoud as master and pioneer of modern \\ French landscape culture}

Corajoud died on 29 October 2014, leaving, after almost fifty years of activity, a great legacy to European and French landscape cultures. 'Les paysagistes ont perdu leur père spiritual' ['Landscape architects have lost their spiritual father'] is the title of just one of the many tributes and recognitions paid to him at the École national supérieure de paysage in Versailles (ENSP), [2] where generations of landscape architects had trained with Corajoud (1971-2000), prior to the decade that he spent at the Institute of Architecture at the University of Geneva.

Corajoud, along with Jacques Simon, his professor and later friend and colleague, took part in the transformation of the original horticultural school of Versailles into France's first school of landscape architecture. Karin Helms (2006), in particular, considers him to have been a pioneer of a process-based landscape architecture, which had originated with
Jacques Simon and to which Corajoud then gave form through a new teaching method based on a project-oriented pedagogy.

Many reflections on Corajoud have developed within different contexts just a few months after his death. In addition to numerous awards from the French establishment, many colleagues, both from France and abroad, have taken significant initiatives. Karin Helms characterized the charisma of Corajoud, who devoted the same attention to design research, landscape teaching, and the definition of new horizons for landscape and neighbouring disciplines, as to 'his fight for the promotion of landscape architecture as a profession and as a discipline that makes crucial contributions to both science and art' (Helms 2014). While some writing produced after the death of a major author can appear hagiographic, Corajoud's œuvre does indeed have great relevance to the field of landscape architecture. Certainly, Corajoud's thinking and work started, from two perspectives, a process of reversal in terms of the established vision of landscape architecture.

The first frame of reference was through Corajoud's reconsideration of the disciplinary position of landscape design as neither opposed to, nor derived from, other related disciplines, such as architecture and planning. From his viewpoint, landscape design and its 'declinations' represented a unique way of designing and perceiving territorial transformations, and thereby ultimately determined the existence of humanity on the planet. This concept was later expressed in Landscape Urbanism, which replaced the previous idea of landscape as a balance to urban growth with the notion that landscape can be the primary determinant of urban transformation.

The second perspective was related to an approach that combines the heritage of French landscape culture with the rural tradition of the country. Corajoud attempted a fusion between the sacred and the profane, between the noble character of French gardens-the grandeur-and the countryside tradition of productive land management, which is more methodical, ra- 


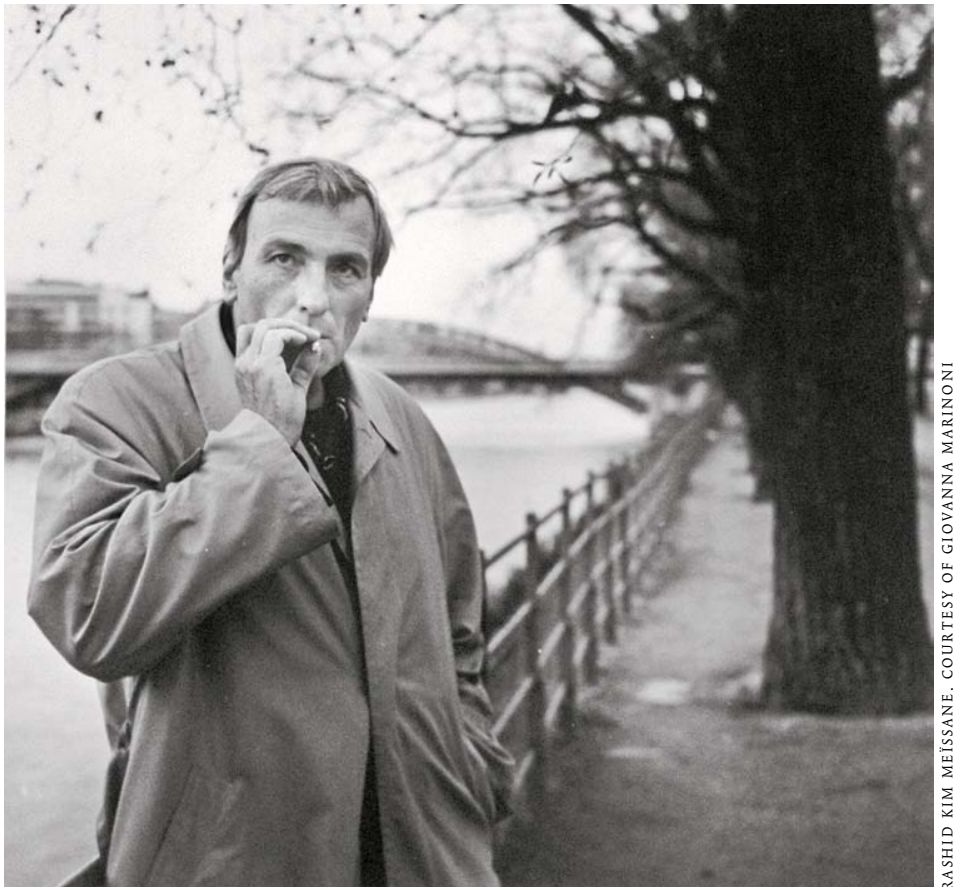

Figure 2 Michel Corajoud portrait (circa 1985)

tional, and Cartesian. He also revived certain great topics of French landscape representation, originating in the culture of Impressionist painting, which exceeds the representation of nature as wilderness and gives more attention to the history of human labour, as well as to the great, epic transformations of the territory.

Corajoud shaped contemporary thinking about landscape in France. The increased output of highly qualified young designers, the improved technical awareness in public administrations, the growth in the quality of plant nurseries and building companies, and the spread of interest in landscape architecture in the cultural arena and in publishing can all be attributed to his tireless work in diffusing and promoting landscape design culture. He also advocated the setting up of a group of 'public landscape architects', as well as the hiring of freelance professionals who work as consultants for public administrations for land management. [3] His conception of landscape architecture has involved an entire nation and established a widespread, solid know-how: in France landscape design does not only represent the practice of a profession, but it coincides with broader ideas of managing a human and natural habitat.

The Corajoud Atelier, led by Claire and Michel Corajoud, had a prolific output and received many awards during his long and productive career. [4] The office seemed to prefer large-scale landscape projects, in a form that does not relate to landscape planning but refers to the deepening of the themes of the garden extended to the large scale. His attitude is bound to the French tradition from Le Nôtre onwards - a tradition to which he somehow felt the heir-which he expressed as an act of government intervention aimed at the general public interest.

One such project is the general plan for environmental requalification of the Plaine Saint-Denis, published in 1992 in Techniques $\mathcal{E}$ Architecture (Corajoud 1992). The project created a sort of ecological urban fabric with regular plant structures in one direction and more organic forms in the opposite one. Another project is the famous Miroir d'eau [Water mirror] of

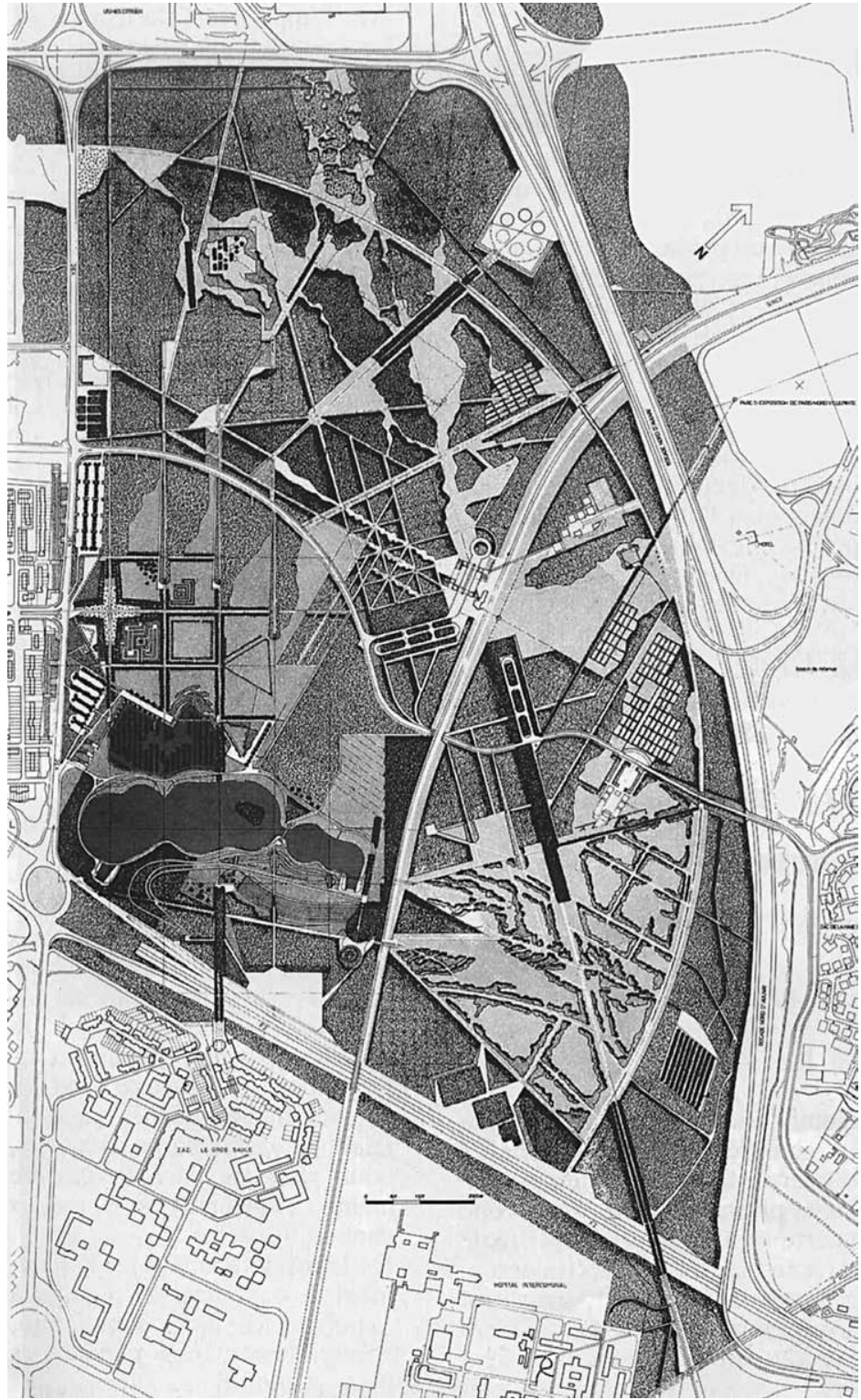

Figure 3 General plan of the park,

from L'Architecture d'Aujourd'hui 262, 1989

the Garonne quay in Bordeaux. The great baignade, a flat pedestrian water surface, perhaps the largest in the world, is the main focus of a public space intervention that covers several kilometers and has been celebrated in many publications. Apart from its great beauty and success, the baignade makes a deep impression on the viewer, due to its ability to transform and transfigure space and induce a different perception of the urban landscape, reflected as a kind of mirage and moving towards infinity.

Among Corajoud's previous achievements one can find two other urban public parks, both designed in 1974: Parc de Villeneuve at Grenoble and Parc des Coudrays at Elancourt-Maurepas. [5] He tested some of the concepts in these two parks that would later be developed at Parc du Sausset. In particular, he experimented with the role of the arboreal systems in the configuration of the spaces, the forms of dynamic perception, and the relationship between dense arboreal surfaces and other elements such as water reservoirs, ground movements, and path structures. Moreover, these early experiences were also much more pronounced in terms of formal and fig- 


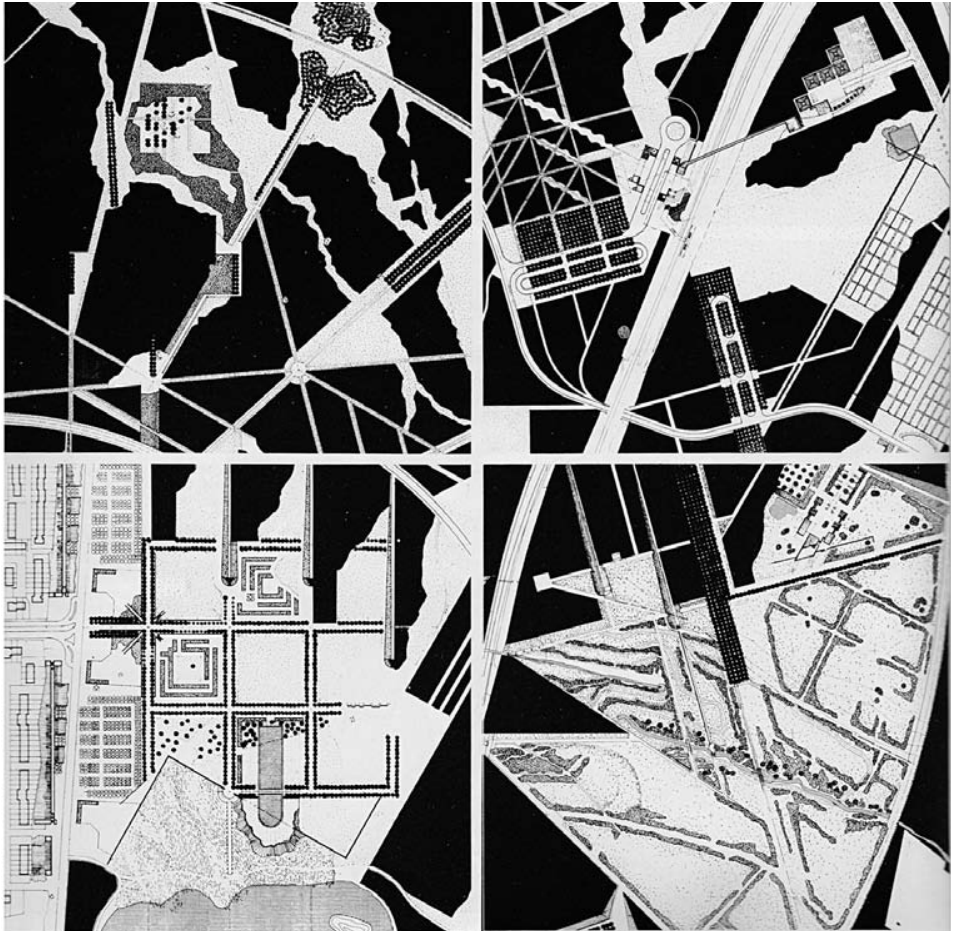

Figure 4 The 'four scenes', details from the competition drawings: the forest, the agri-horticultural scene with station, the city park, the bocage, from L'Architecture d'Aujourd'hui 218, 1981: 58

urative approach: 'At Grenoble, Corajoud created clearly readable forms that seem to refer to Léger's figurative world' (Zagari 1988). This project reflects his original training at the School of Fine Arts, where he had been a student of Bernard Rousseau-sculptor and collaborator of Le Corbusieran experience that perhaps prompted his declared membership in the world of the figurative and architectural avant-garde of the modern era. The results of the competition for Parc du Sausset are well documented in a special issue of L'Architecture d'Aujourd'hui (issue 218, 1981), which is entirely devoted to French landscape projects and experiments of that period. The following descriptions are taken primarily from the project report published there and other French literature. Hargreaves notes that in the Anglo-Saxon world 'Surprisingly, Parc du Sausset has received little critical attention', with the result 'that most of us are familiar with only a handful of images' (Czerniak \& Hargreaves 2007: 155). By contrast, the French publishing world that has produced many studies about this park.

The above-mentioned special journal issue, edited by Corajoud, offers an overview of the first decades of active militancy in France's landscape culture and of the formation of a school that reflected his ambitions and those of its founder, Jacques Simon. But, it is also the cultural manifesto of the type of design and the theoretical production that defined the French landscape scene of the time. Corajoud used the opportunity to edit the special issue of L'Architecture d'Aujourd'hui to strengthen and amplify the impact of theoretical reasoning on the landscape that was gaining depth in France. He also edited a discussion forum, inviting several French architects to comment on the relationship and distance between architecture and landscape architecture.

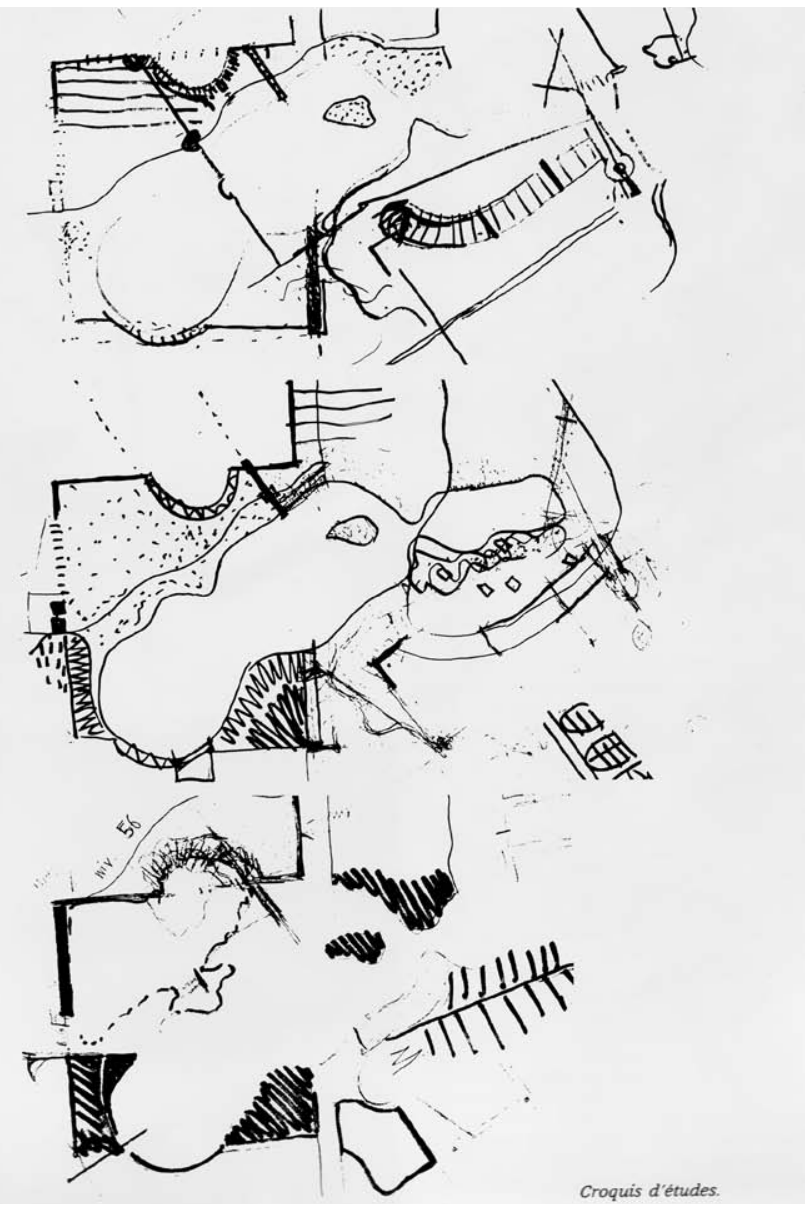

Figure 5 Study sketches for the layout of the basin of Savigny, from L'Architecture d'Aujourd'hui 218, 1981: 59

The park and its context

The set-up of the competition project team for Sausset was very complex and changed during subsequent stages. [6] Claire and Michel Corajoud involved many professionals from different fields ensuring a multidisciplinary approach - a choice that became his own distinctive note, as well as in his teaching, and that today appears to be an essential methodology. Later on, some members of this team became well-known for their personal, independent work, such as Claude Guinaudeau with his urban forestry and préverdissement techniques, and Pierre Donadieu, who founded his theoretical contributions to the themes of urban agriculture and urban fringe on the further development of many embryonic ideas fostered by the competition. [7]

Parc du Sausset is situated in the department Seine-Saint-Denis, close to Roissy Airport northeast of Paris, and occupies a residual part of a fragmented agrarian territory, regarded by the French as one of the most fertile in the country (Corajoud \& Corajoud 1981). Even in countries like France, where urban sprawl is generally kept under control, the increase in suburban growth had created large urban fringes by the second half of the twentieth century. Originally, these territories were used for intensive crops and had lost their function and identity, as well as their meaning as rural entities, due to the excessive territorial fragmentation. The Parc 


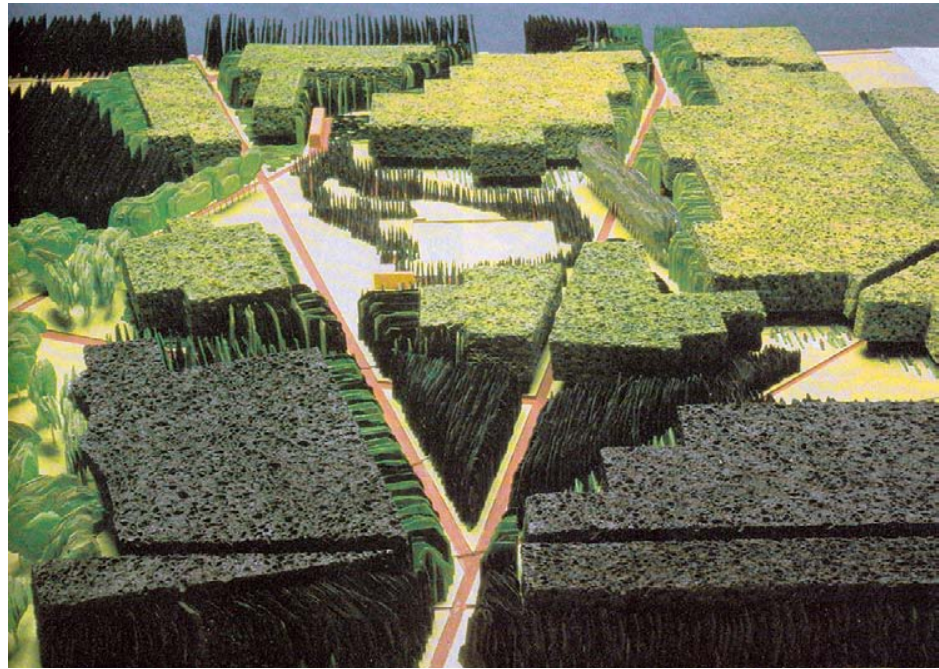

Figure 6 View of competition model, from:

L'Architecture d'Aujourd'hui, 218, 1981: 57

du Sausset project anticipated current debates on urban fringes and their re-design, in order to create new opportunities for the revalorization of suburbs.

The park occupies an area resulting from three settlements: the highly populated immigrant public housing quarter of Aulnay-sous-Bois in the south, the Villepente municipality with its middle-class houses and the large exhibition centre in the east, and the Parc des Expositions Paris-Nord Villepinte in the north and west. In terms of its insertion in the ecological fabric, the park lies to the west, almost in the form of an appendix, of a large agricultural and state forest zone that accompanies Rue Francilienne, a ring road on the eastern side of Paris. At about 15 kilometres to the west is Parc de La Courneuve, today named Parc Georges-Valbon. Covering approximately 200 hectares, its aim was to give a new sense of identity to the space by integrating parts of the residual agricultural activities and creating new connectivities in an area deeply marked by the presence of key infrastructures: the RER regional train system with its station in the focus point of the park, highway connections with the Roissy-Charles Airport de Gaulle, the Rue Francilienne, and the Parc des Expositions.

In the nineteenth century, the first great urban parks, Bois de Boulogne and Bois de Vincennes, were created in the vicinity of the city limits, where the Boulevard Périphérique lies today; Parc du Sausset is situated 20 kilometres further away. Growth in concentric rings around the metropolitan area of Paris is still being accompanied by the creation of large parks. The park is situated where the Boulevard Intercommunal du Parisis meets Rue Francilienne and, along with other public park areas or state forests, creates a unique pattern or system of green areas in the north of Paris.

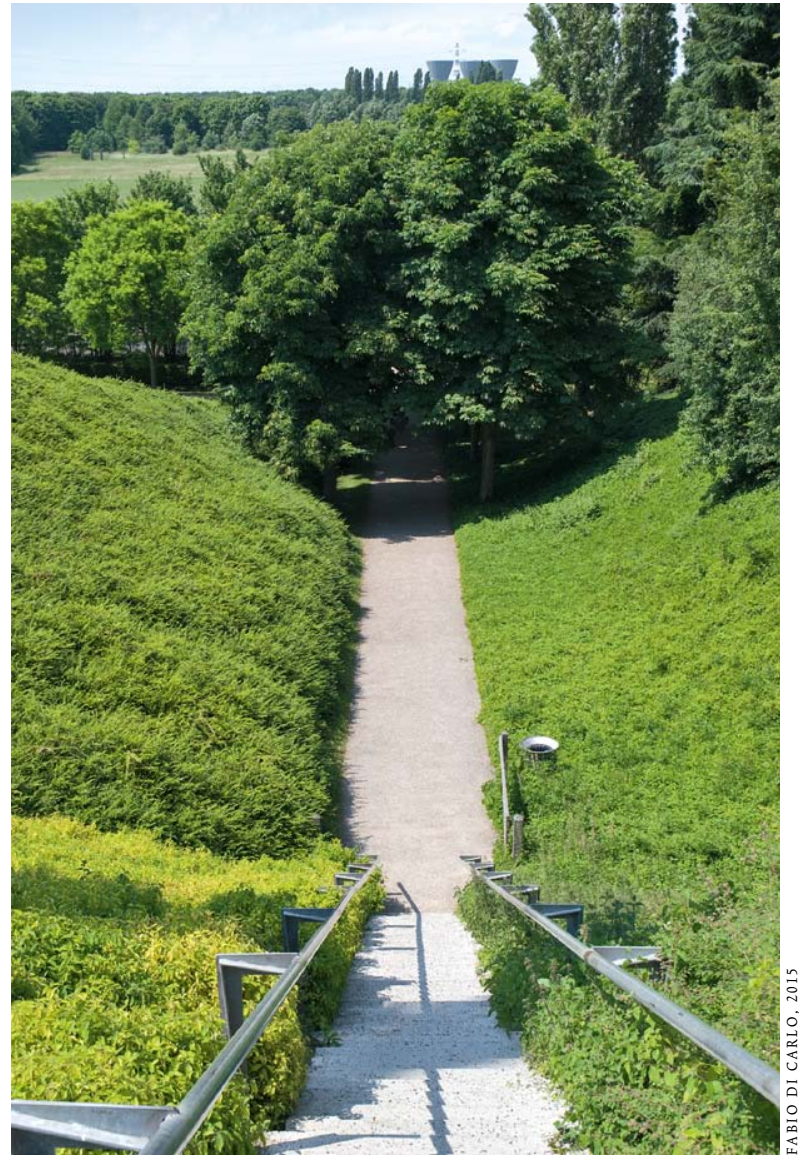

Figure 7 View from top of the Vertugadin, with water towers as landmark. The Vertugadin (farthingale) is a double-sloped side of the main basin.

Four great scenes and a large community of trees

The park organization is based on the formal and spatial articulation of arboreal systems, as a matrix and unique material for the creation of its densest sections. These woods are punctuated with large voids, glades, and the path system. The implementation of the voids and path system is realized almost exclusively through the clipping of dense arboreal surfaces, or by the creation of geometric wood structures, with a large repertoire of regular or irregular shapes. The first construction phase involved the planting of 400,000 trees: a widespread agro-forestry system that would shape the entire park. The main arboreal choices were woods of beech trees, oaks, and ashes that created a strong contrast with the dark pinewoods. A high-density planting system, of originally up to $1.5 \times 3 \mathrm{~m}$ (Leblanc $\mathcal{E}$ Coulon 1993), was used to create tree enhancement nurseries on the site and increase the impact of the forest immediately after installation. The realization of the planned works was phased over a period of twenty-five years. Today, the park is almost completed and has been open to the public since the early 1980s, but Claire Corajoud, the co-designer of the project and the person directly responsible for its implementation since 1990 , informs us that to date a north-eastern portion of about 29 hectares, called the "Well of the Hell', has not been realized due to a lack of government funding. 


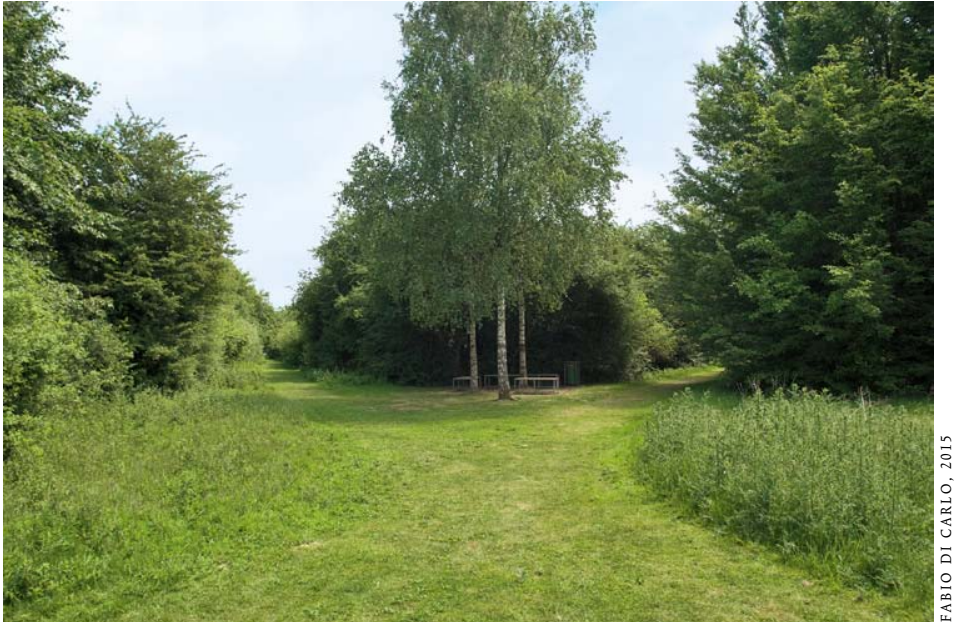

Figure 8 A patte-d'oie (crow's foot) inside a forest area

The project's layout elegantly integrates passages and a vocabulary from landscape history, reinterpreting them in a contemporary way-a lucky conjugation between the aulic language of French garden history and signs, as well as methods and elements, derived from the agrarian tradition. Although the neoclassical and modern tendency of exerting power over nature is reinterpreted here, the language is derived not only from this national heritage, [7] but also from the legacy of large nineteenth-century European urban parks such as the ones in London, Berlin, and Paris. According to Malene Hauxner (2006), Parc du Sausset's design language is based on the dialectics of contrasts, the Apollonian and the Dionysian, as it uses nature / artifice, clear / opaque and urban / rural pairs.

Thus, the project well represents the dialectic between rationalist objectivity and the rising trends in approaches to complexity of that period. The concept for the park tries to establish an innovative dialectic that rejects both the tired repetition of ideas of late modernism, and the uncritical adherence to certain linguistic expressions of postmodern architecture. Thus Corajoud shows a stricter adherence to the philosophical aspects of postmodernism, with more attention to the social impact of the project and to his own linguistic expression.

Elements of the countryside pattern, such as horticultural plots, hedgerows, bocage, and water systems, integrate and realize a continuous alternation of opening and enclosing views. Extended surfaces, or linear forests, are opposed to large glades giving the park 'une complexité qui n'aurait que le végétal comme texture' ['a complexity that will have vegetation as texture'] (Corajoud $\mathcal{E}$ Corajoud 1981), thus emphasizing the prevalent use of vegetation as its main design element. Regarding the design method, the Corajouds also affirmed that 'A l'inverse d'un projet articulant des fonctions, là, il s'agit d'articuler des lieux' ['As opposed to a project that organizes functions, the proposal organizes places'] (Corajoud \& Corajoud 1981). A layered network of paths and a system of five large main 'scenes' revolving around the presence of the train station form the park structure and also fulfill ecological requirements. [8] The network allows the reunification of the separate parts and provides a strong pedestrian link between the core of the park-with train station, bus stop, and parking lot-and the settlements: in this way the layout of the park has become part of the local inhabitants' everyday life.

The four original scenes define different ways of inhabiting the park: the scène forestière, which occupies the main part of the plateau, is home to the urban park life; [9] the scène agri-horticole, the agricultural or horticultural scene, is near an eco-museum on the Plaine de France that emphasizes the

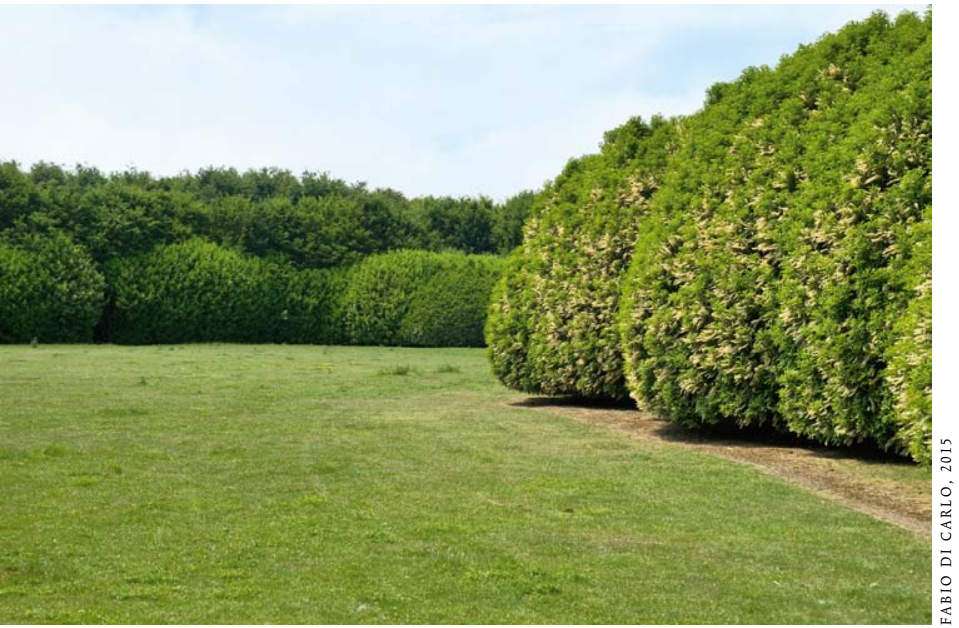

Figure 9 Large clearing inside the forest

well-known high quality of the soil; the scène bocagère, or the hedge scene, consists of wide open spaces surrounded by tall hedgerows; and, finally, the scène de parc plus urbain, the city park scene, includes the large Savigny basin and a system of more urban gardens, close to the residences, mediating between the city and the park. Urban gardens are 1 hectare each and include a labyrinth and other recognizable forms from garden history. A fifth scene, called Vertugadin, literally 'farthingale', is a steeply sloped side of the Savigny basin, probably created after the first stage to look at the horizon from a privileged point of view; a vision that includes the basin itself, the wetland and, further on, the new forests.

The scenes themselves offer alternative and modern interpretations of landscape archetypes, different tools useful to 'decline' and shape the scenes. The resumption of elementary forms of French landscape - well outlined in the collective imagination of the people-is a medium for understanding the park and a vehicle for the creation of identity. There are 'cinq registres de formes paysagères' ['five registers of landscape forms']: la patted'oie, la clairière, le boqueteau, les entames cultivées, les haies bocagères. (Corajoud $\mathcal{E}$ Corajoud 1981). Patte-d'oie is the main pattern of the park that organizes the forest structure, a contemporary reinterpretation of a traditional form that can be found in many urban parks, such as the Tiergarten in Berlin, here reinterpreted in a more fragmented layout, with an exploded radiality that replaces the symmetry. The clairières de bois are glades-ranges of light within the fabric of the forest that give security, transforming the unquiet forest into a more familiar and cosy place. Boqueteaux are small groups of trees or groves that mark the large open spaces. Entames cultivées are cultivated areas in the form of urban plots or small urban farms. Haies bocagères include the field boundaries and natural hedges and function as places of biodiversity conservation. Haies bocagères are also the basis for large-scale spatial organization in the park. In addition to the "city park scene', there are also other, recurring figures such as large, regular court systems containing gardens and multiple paths. Complex and organic geometries are continuously relating to large alignment structures and open spaces, reinventing the dialectics between natural and artificial forms.

The planting and cultivation programme lasted for more than twentyfive years. In this way, the park became a place of continuous work, including a sector with a tree nursery for very young plants, instant green parts created through the immediate installation of mature plants, and other cultivated areas of different densities. 


\section{A large park and an evolutionary machine}

Parc du Sausset was created after the design competition organized in 1979, in an attempt to reconstruct an environmental system of connections in a fragmented agrarian territory. It is a new, large park, approximately 200 hectares in size, that has as its antecedent the nearby, and even larger, Parc de la Courneuve, which is about 415 hectares. Courneuve is less unified in structure than Sausset, due to the three different stages of its development and layouts, ranging from the 1935 original to the newest by Alain Provost (1972-2000); it is also more traditional, much more related to the tradition of the Parisian bois and other nineteenth-century parks (Corner $\mathcal{E}$ Marot 1999).

With regard to the general theme of 'large parks', George Hargreaves noted that the large park 'affords the scale to realistically evaluate the degrees to success or failure of many of the issues embedded in public landscape: ecology, habitat, human use and agency, cultural meaning, and iconographic import[, which] cannot be understood without considering the physical characteristics of the site itself (Czerniak $\mathcal{E}$ Hargreaves 2007). Though smaller when compared to the more recent international realizations of large parks, [10] Corajoud tries in Sausset to give a twenty-first century perspective to the complex themes of ecology and human agency while creating a new consciousness of the environment and a new social identity.

A major innovation in the park is the emphasis on the role of temporal dynamics and their relationship to the landscape, which is mainly expressed through the long-term evolution of the forest systems and the short and cyclical variations of the water system. 'Le parc du Sausset m'apparaissait comme une immense machine vivante. Ce milieu végetal était conçu selon un processus intégrant le temps: des relais organisaient la succession des croissances, l'aléa était mis en œuvre' ['Parc du Sausset appeared to me like a huge living machine. This plant community was designed as a process of time integration: the relay organized the succession of growth, the hazard was implemented']. This brief description by Michel Desvigne (1989) summarizes the idea of the park: the courage to take the vagueness and uncertainty of the evolution of plant systems as the means of defining the project.

The first published images of Sausset (Corajoud 1989; Zagari 1988) show a very young landscape, small plants in large areas, similar to a tree nursery, interspersed with mature plants that have an instantaneous effect. It was an environmental system designed to develop and complete itself during a lifetime; a visit to the park in the early 1990s would essentially confirm the representation of the park in contemporary publications, such as in the essay in Paysages by Leblanc and Coulon (1993). It was in an intermediate stage of development and growth at that time, and perhaps the original design structure was more legible than today.

In drawing on a definition of 'large park', and as fundamental factors for its future success, Hargreaves gives priority to the adaptive capacity of a project, and to the mediation between the designer's will and the physi- cal characteristics of the site, as well as to the readability of these dialectics. At the same time, he finds that, despite the success as a theoretical antecedent of contemporary ecological practices in public park design, there is in Sausset a certain contradiction in the management of the forestry forms. 'The invasion of a monoculture or another may occur', in contrast to the Corajoud rhetoric, which searched for a balance between spontaneity and 'worked nature' with a fairly intensive maintenance regime (Czerniak $\mathcal{E}$ Hargreaves 2007: 158).

The water regime is a further innovation in the park, with the original retention basin of Savigny as its centre stage. The theme of water extends to the configuration of a large, floodable area around the basin and includes, in advance of now more prevalent practice, a reference to the ecological role of these systems as stormwater filters. Another element that anticipates current trends in the use water systems in urban environments is flooding water, which emphasizes factors of uncertainty and variability in the park.

The organization of woodlands, wetlands, and large open spaces imposes a long-term framework on the park management in Sausset, which should be studied and analyzed also in terms of the relationship between best practices for urban park areas and a perceptible expression of design processes. In fact, Parc du Sausset is intended to express a time concept that is not only linked to the maturation of the plant systems and colour alternations, but also to a significant change in its configuration, structure, and perceivable forms.

These innovations in water regimes and arboreal structures were to become a kind of distinctive signature for Corajoud and his closest collaborators. Examples of innovative water regimes are Alexandre Chemetoff s redevelopment of the Schlumberger site in Montrouge and many recent projects by Henry Bava (Agence Ter), where similar devices in the urban environment reinvent the role of water in the public space. Examples of arboreal structures inspired by Parc de Sausset can be found in the work of Michel Desvigne and Christine Dalnoky, who many times used the growth of trees and alternative forms of management as a defining principle of their projects. In the park on Greenwich Peninsula (1997), they implemented progressive tree plot thinning, from a plant nursery structure to the final form of the park. In an earlier project for the Thomson Factory in Guyancourt (1992), the use of rapid-growing and short life cycle plants, and a plan of selected removals, had the initial Cartesian structure gradually evolved into the opposite form of a naturalistic park. The work of Gilles Vexlard and Latitude Nord for the Riem Landscape Park in Munich also seems to reference Sausset in its large-scale organization through strict arboreal geometries; the relationship created between grasslands and large forest fragments appears even more radical than that of Corajoud's park. 


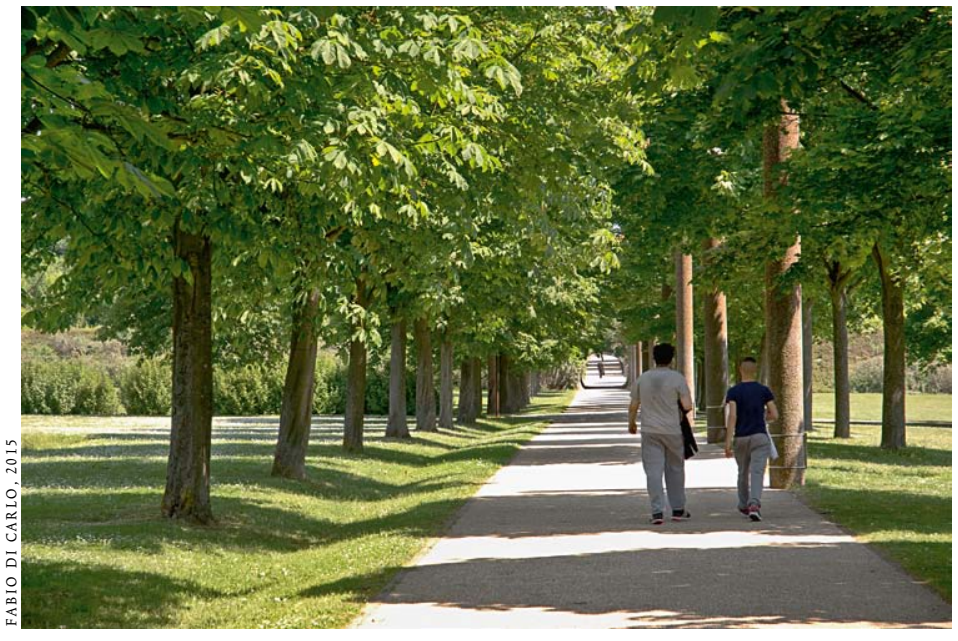

Figure 10 The main connection between the station and the city through the park

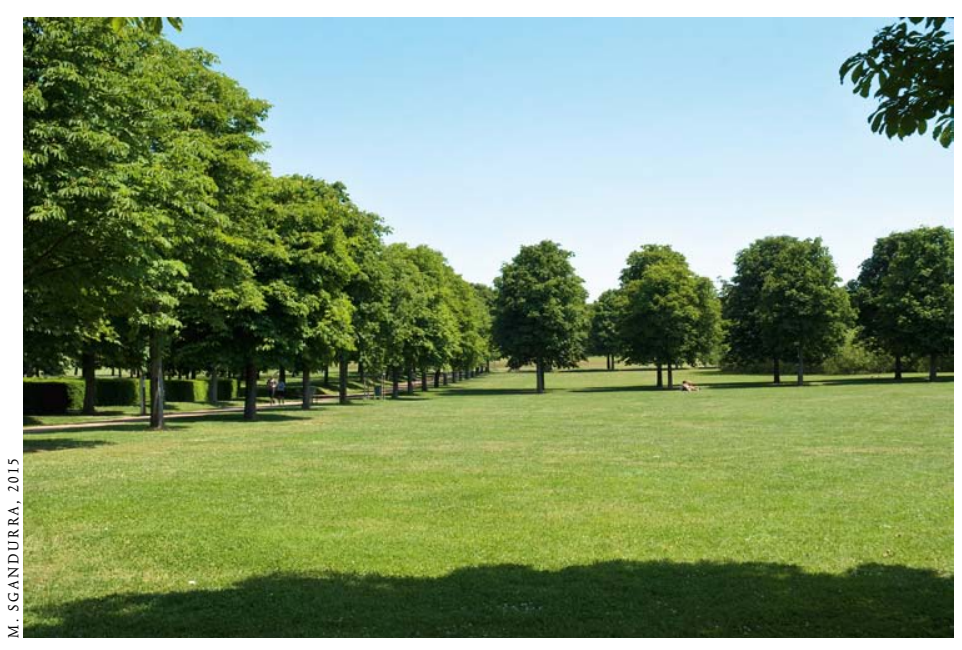

Figure 12 The large garden courts

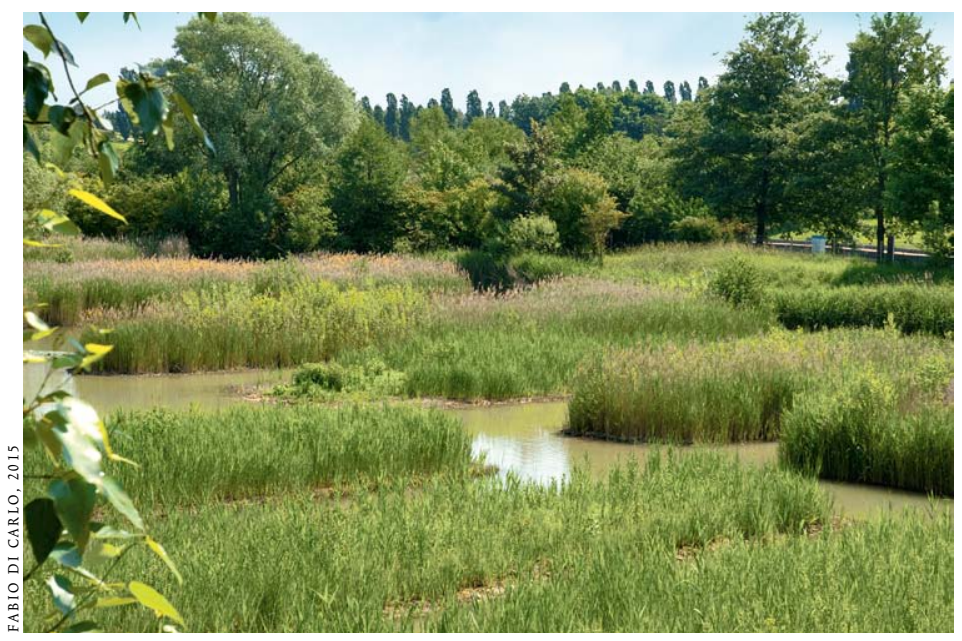

Figure 14 The wetland beside the basin of Savigny

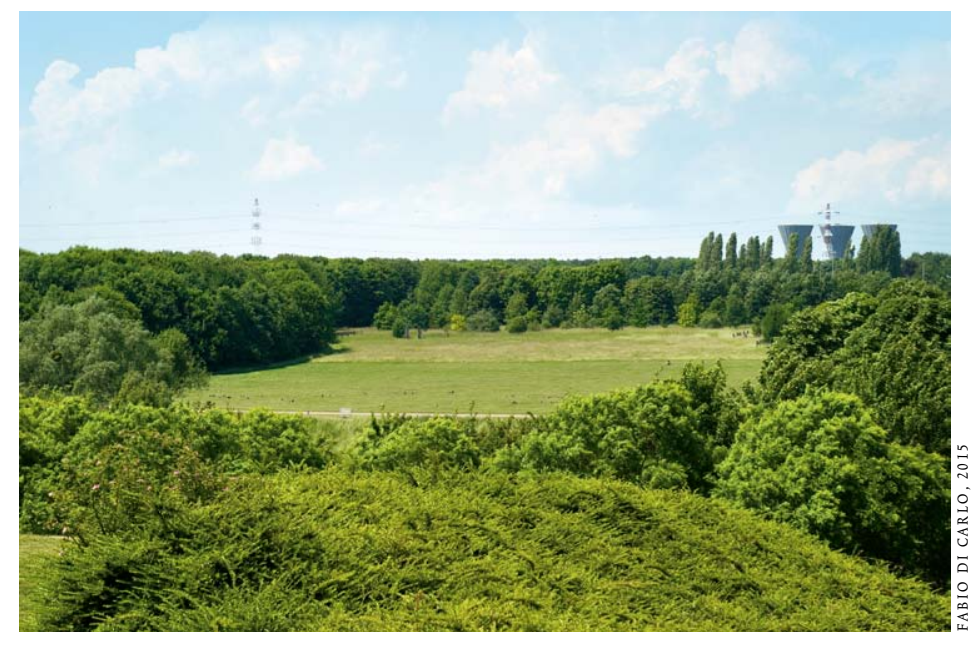

Figure 11 Today's view of the forest, thirty years after the planting

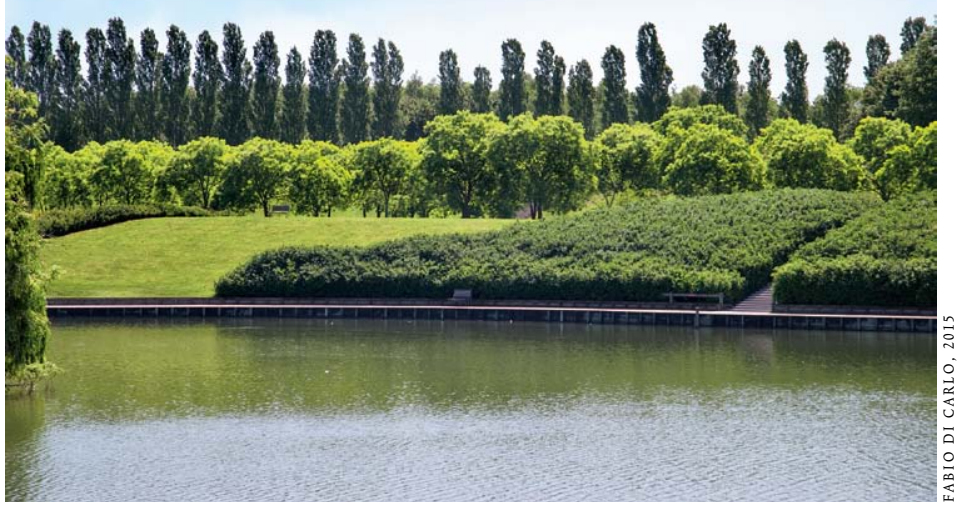

Figure 13 The basin of Savigny and the Vertugadin slope with different shapes and colours of vegetation

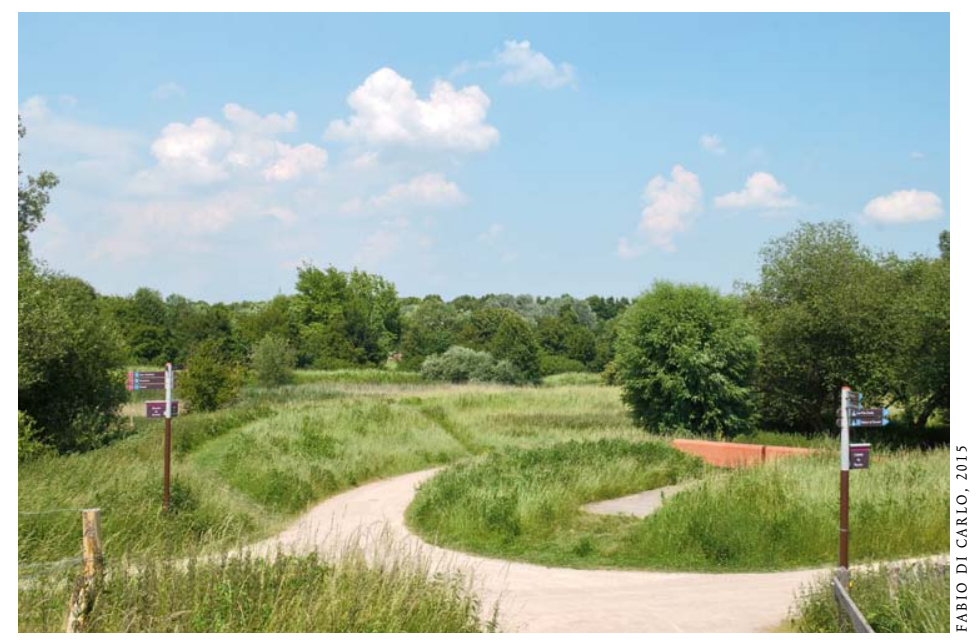

Figure 15 Entrance to the bocage area 

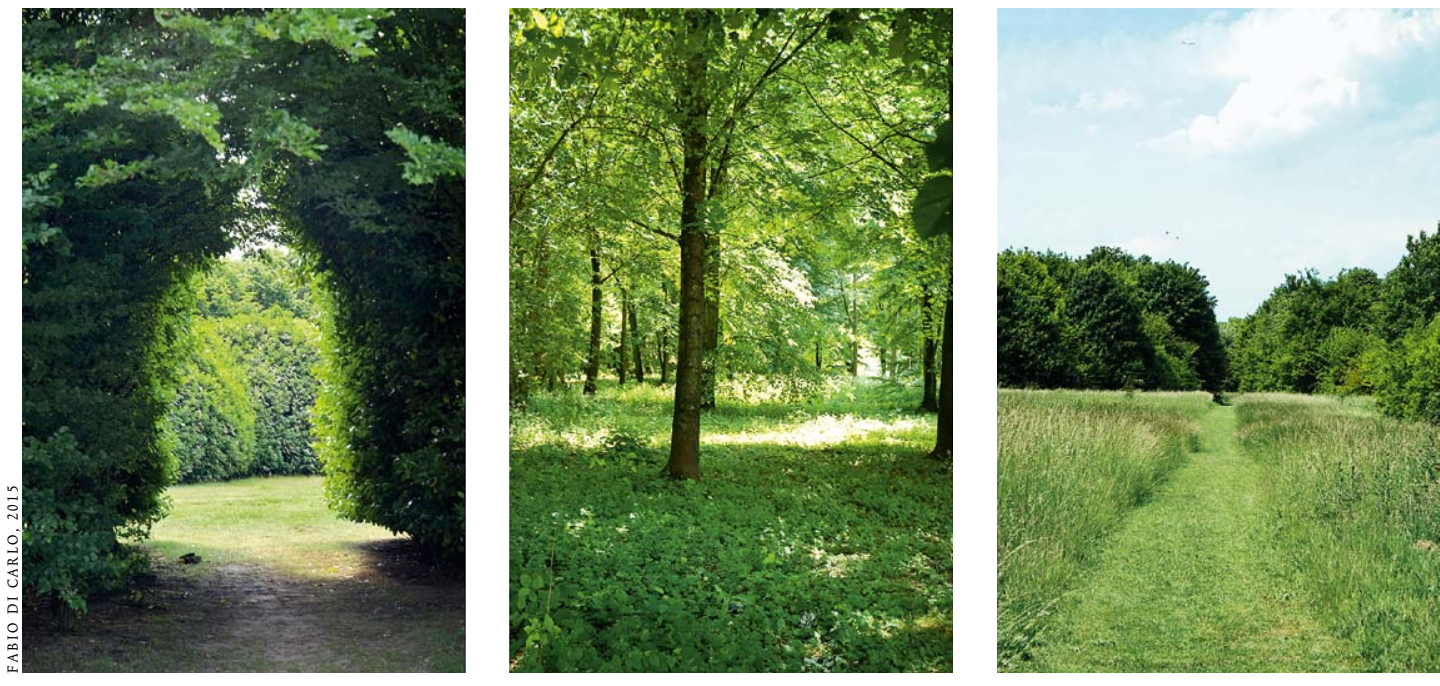

Figure 16 The forest system and the different qualities of light

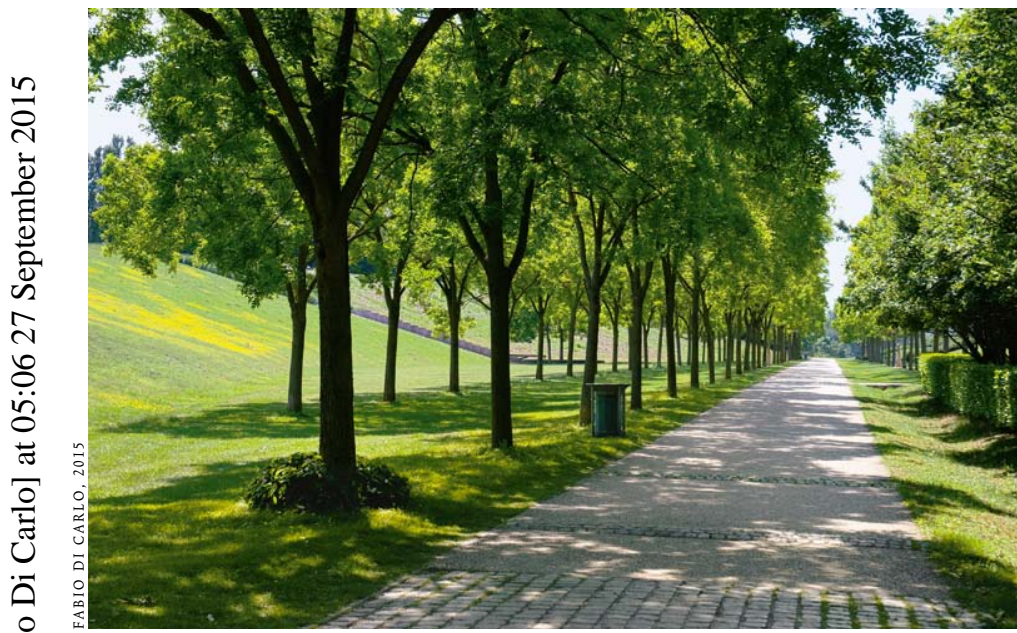

Figure 17 The slope of the Vertugadin
'There is no landscape without horizon'.

Actuality and legacy of the park

Reflections on the theme of the horizon accompanied Corajoud for most of his life and took on different meanings. One of these is more directly perceivable, referring to the different distances that figure in the construction as well as in the interpretation of the landscape. Another is probably more metaphorical in nature, linked to the construction of a comprehensive vision of the themes of landscape, from landscape teaching and formation to the spread of a landscape culture.

I have recently visited the Parc du Sausset. It is now mature and wellkept, with no graffiti or signs of vandalism and it looks like a well-established and appreciated place that is highly enjoyed by the people. Today, Sausset has become an integral part of the identity of its region. It anticipated the demands for ecological and social sensitivity that were written into the European Landscape Convention, adopted by the Council of Europe in 2000. Sausset has also been ranked in Nature 2000, due to its high level of biodiversity and the presence of numerous bird species.

Parc du Sausset appears well-calibrated for its role: it is not just a leisure park, but an essential element for the social and ecological functioning of the northern outskirts of Paris, due both to its scale and the relationships it enables and the development of a collective environmental awareness. At the same time, the strength of the forest structures obviously manifests itself as being part of a wider environmental system. Therefore, the park is not a compensation of urban development but rather an element that becomes part of the overall quality of a territory.

Today, some of these ideas may seem simply rhetorical and have become nearly emptied out by their ubiquity. Some elements of Parc du Sausset could appear not as inventions, but reinterpretations of elements of landscape history. However, what is innovative is the overall combination of these ideas and elements, making Parc du Sausset a successful reference for other landscape projects.

The forests have become a recognizable regional element by defining and framing the view of travellers going from Roissy Airport to Paris. In a similar way, they unfold a variety of visible horizons to those who stroll or run through the park, giving form to Corajoud's ultimate goal of creating new horizons through the work and the construction of landscapes. 


\section{ACKNOWLEDGEMENTS}

First, I want to thank Mrs. Claire Corajoud for her precious information regarding the status of realization of the park and for kindly making materials from the Atelier Corajoud website available to me. Furthermore, special thanks to Giovanna Marinoni, who spent many years close to Corajoud, for the friendly support she gave me for this essay. Also, many thanks to Ana Horhat for her valuable collaboration in the research of sources. And, finally, my gratitude to Gianna Attardo for her most helpful and enlightening revisions of the English text.

\section{NOTES}

1 For a detailed reading of the landscape culture in France after World War II, see Helms (2006) and Blanchon-Caillot (2007).

2 Memory by C. Alban, landscaper, who was Corajoud's student in 1999. For other memories from colleagues, students, and friends, see the web page of École national supérieure de Paysage (ENSP), www.ecole-paysage.fr/site/ensp_fr/index.htm, accessed 12 January 2015.

3 Association des Paysagistes-Conseils de l'État (APCE).

4 Among the most important prizes he received are the Grand Prix du Paysage in 1992, the Grand Prix de l'Urbanisme in 2003 for the project of the Garonne Quay in Bordeaux, and the first edition of Prix international André Le Nôtre in 2013.

5 These parks were designed, both in 1974, together with the architects Henri Ciriani and Borja Huidodro, within Corajoud's participation in the Atelier d'urbanisme et d'architecture (AUA).

6 The project team was originally composed of Claire and Michel Corajoud, landscapers, with Jacques Coulon (first phase); Edith Girard and Pierre Gangnet, architects; Pascal Mourgue and Patrice Hardi, designers; Bernard Rousseau, sculptor; Tristan Pauli, Claude Guinaudeau, Pierre Donadieu, Marc Rumelhart, Jean Baptiste Page, agricultural and forestry engineers, and others.

7 Corajoud was also one of the main researchers of Le Nôtre's works: Corajoud, M., Coulon, J., and Loze, M. H. (1983), 'Versailles, lecture d'un jardin', Annales de la recherche urbaine 18-19 June 1983 [Paris: Dunod].

8 Corajoud had a long collaboration with his school's Ecology Department, particularly with Marc Rumelhart and Gabriel Chauvel, which probably contributed to his focus on the use of ecological devices and processuality in landscape projects.

9 On the topic of the woods, neighbourhood, and urban forest as a means of urban public space, some interesting studies have been recently conducted by U. Åkerlund, U. and R. Gustavsson (2004) as well as C. C. Konijnendijk (2008).

10 Czerniak and Hargreaves (2007) proposed a comparative table of large parks, from 200 to 3,000 hectares, in which Sausset turns out to be the smallest in the selection.

\section{REFERENCES}

Åkerlund, U., Gustavsson, U. and R. (2004), The Skrylleskogen Study: Interactions Between Coming Managers and Connoisseurs on the Way to a Refined Management Planning (Alnarp: Department of Landscape Planning).

Blanchon-Caillot, B. (2007), 'Pratiques et compétences paysagistes dans les grands ensembles d'habitation, 1945-1975', Strates 13.

Brunon, H. and Mosser, M. (2005), Le jardin contemporain (Paris: Scala), 36-39.

Canogar, S. (1997), 'Figuras del paisaje', Arquitectura Viva 53: 28.

Chemetoff, A., Clément, G., Corajoud, M., Huet, B., and Desvigne, M. (1989), 'Paysage. On aimerait tant photografier un paysage de dos', L'Architecture d'Aujourd'hui 262: 32-38

Corajoud, C. and Corajoud, M. (1981), 'Project LauréatParc du Sausset', L'Architecture d'Aujourd'hui 218: 56-59.

Corajoud, M. (1982), 'Le paysage c'est l'endroit ou le ciel et la terre se touchent', in F. Dagognet et al. (eds.), Mort du Paysage? Philosophie et Eshétique du Paysage (Seyssel: Les éditions Champ Vallon).

Corajoud, M. (1992), 'Stratégie de crise',

Techniques \& Architecture 403: 76-81.

Corajoud, M. (2003), 'Geometriè e tracès', in M. Corajoud, A. Masboungi, and E. Allain-Dupré (eds.), Grand prix de l'urbanisme 2003: Michel Corajoud et cinq grandes figures de l'urbanisme (Paris: Ministère de l'équipement, des transports, du logement, du tourisme et de la mer).

Corajoud, M. (2008), 'The complexity, the moderation, the restraint', Paisea 7: 7-11.

Corajoud, M. (2010), Le paysage, c'est l'endroit où le ciel et la terre se touchent (Arles/Versailles: Actes Sud / ENSP).

Corner, J. (1999), Recovering Landscape: Essays on Contemporary Landscape Theory (Princeton, NJ: Princeton Architectural Press).

Cortesi, I. (2000), Il parco pubblico-Paesaggi 1985/2000 (Milano: Motta), 150-155.

Cruz, G. T. (ed.) (2012), The French Mind On The Landscape. A Selection of Relevant Articles Translated from Selected French Texts (Bloomington, IN: XLibris).

Czerniak, J. and Hargreaves, G. (2007), Large Parks (Princeton, NJ: Princeton Architectural Press).

Desvigne, M. and Dalnoky, C. (1996), Desvigne \& Dalnoky (Milano: Motta).

Donadieu, P. (1998), Campagnes urbaines (Arles: Actes Sud). Donadieu, P. (2002), La société paysagiste (Arles: Actes Sud). Guinaudeau, C. (1987), Planter aujourd'hui, bâtir demain: le préverdissement (Paris: Collection Mission du paysage).

Helms, K. (2006), 'The Pioneers', in LAE Foundation (ed.), Fieldworks (Basel: Birkhäuser).
Helms, K., 'A masterful landscape architect and a generous teacher', www.toposmagazine.com/?s=corajoud, accessed 20 January 2015

Konijnendijk, C. C. (2008), The Forest and the City. The Cultural Landscape of Urban Woodland (New York: Springer-Verlag).

Proszynska, V. and Corajoud, M. (2000), Michel Corajoud (Paris: Hartmann).

Reed, P. (2005) Groundswell: Constructing the Contemporary Landscape (New York: MOMA).

Tate, A. (2004), Great City Parks (London/New York: Spoon Press).

Zagari, F. (1988), L'architettura del giardino contemporaneo (Milano/Roma: Mondadori-De Luca).

\section{BIOGRAPHICAL NOTES}

Fabio Di Carlo is Associate Professor of Landscape Design in the Department of Architecture and Design (DiAP) at Sapienza University of Rome, where he teaches in the Master's programme in landscape architecture and the Postgraduate School in Natural and Territorial Resources. He holds $\mathrm{a} \mathrm{PD}$ in Environmental Design and is also an architect. As a designer of gardens, parks, public spaces, and landscapes he has taken part in a number of national and international competitions, projects, and research studies. At "La Sapienza" he is also a member of the teaching board of the $\mathrm{PhD}$ programme in landscape and environment. He has taught Master's courses at several universities internationally, among them Tsinghua University in Beijing and the University of Liège in Belgium. He has been a reviewer for the Italian Ministry of Education since 2006 and a member of the Executive Committee of ECLAS, the European Council of Landscape Architecture Schools. His book Paesaggi di Calvino (Melfi: Librì) was published in 2013.

\section{CONTACT}

\section{Fabio Di Carlo}

Dipartimento di Architettura e Progetto

Sapienza University of Rome

Via Flaminia 359

00196 Rome, Italy

Phone: $+390632101220 / 29+393388436188$

fabio.dicarlo@uniromal.it 